\title{
A $\mathrm{H}_{2} \mathrm{~S}-\mathrm{Nampt}$ Dependent Energetic Circuit Is Critical to Survival and Cytoprotection from Damage in Cancer Cells
}

\author{
Reiko Sanokawa-Akakura', Elena A. Ostrakhovitch ${ }^{1}$, Shin Akakura ${ }^{1}$, Scott Goodwin ${ }^{2}$, \\ Siamak Tabibzadeh ${ }^{1,2 *}$
}

1 Frontiers in Bioscience Research Institute in Aging and Cancer, Irvine, California, United States of America, 2 Dept of Radiological Sciences, University of California Irvine, Irvine, California, United States of America

\begin{abstract}
We recently demonstrated that cancer cells that recover from damage exhibit increased aerobic glycolysis, however, the molecular mechanism by which cancer cells survive the damage and show increased aerobic glycolysis remains unknown. Here, we demonstrate that diverse cancer cells that survive hypoxic or oxidative damage show rapid cell proliferation, and develop tolerance to damage associated with increased production of hydrogen sulfide $\left(\mathrm{H}_{2} \mathrm{~S}\right)$ which drives up-regulation of nicotinamide phosphoribosyltransferase (Nampt). Consistent with existence of a $\mathrm{H}_{2} \mathrm{~S}-\mathrm{Nampt}$ energetic circuit, in damage recovered cancer cells, $\mathrm{H}_{2} \mathrm{~S}$, Nampt and ATP production exhibit a significant correlation. Moreover, the treatment of cancer cells with $\mathrm{H}_{2} \mathrm{~S}$ donor, $\mathrm{NaHS}$, coordinately increases Nampt and ATP levels, and protects cells from drug induced damage. Inhibition of cystathionine beta synthase (CBS) or cystathionase (CTH), enzymes which drive generation of $\mathrm{H}_{2} \mathrm{~S}$, decreases Nampt production while suppression of Nampt pathway by FK866, decreases $\mathrm{H}_{2} \mathrm{~S}$ and ATP levels. Damage recovered cells isolated from tumors grown subcutaneously in athymic mice also show increased production of $\mathrm{H}_{2} \mathrm{~S}$, Nampt and ATP levels, associated with increased glycolysis and rapid proliferation. Together, these data show that upon recovery from potential lethal damage, $\mathrm{H}_{2} \mathrm{~S}-\mathrm{Nampt}$ directs energy expenditure and aerobic glycolysis in cancer cells, leads to their exponential growth, and causes a high degree of tolerance to damage. Identification of $\mathrm{H}_{2} \mathrm{~S}$-Nampt as a pathway responsible for induction of damage tolerance in cancer cells may underlie resistance to therapy and offers the opportunity to target this pathway as a means in treatment of cancer.
\end{abstract}

Citation: Sanokawa-Akakura R, Ostrakhovitch EA, Akakura S, Goodwin S, Tabibzadeh S (2014) A $\mathrm{H}_{2}$ S-Nampt Dependent Energetic Circuit Is Critical to Survival and Cytoprotection from Damage in Cancer Cells. PLoS ONE 9(9): e108537. doi:10.1371/journal.pone.0108537

Editor: Stefan Strack, University of lowa, United States of America

Received May 29, 2014; Accepted August 27, 2014; Published September 23, 2014

Copyright: ( 2014 Sanokawa-Akakura et al. This is an open-access article distributed under the terms of the Creative Commons Attribution License, which permits unrestricted use, distribution, and reproduction in any medium, provided the original author and source are credited.

Data Availability: The authors confirm that all data underlying the findings are fully available without restriction. All relevant data are within the paper and its Supporting Information files.

Funding: The authors have no support or funding to report.

Competing Interests: The authors have declared that no competing interests exist.

*Email: fbs@bioscience.org

\section{Introduction}

In recent years, it has been shown that gasotransmitters, nitric oxide $(\mathrm{NO})$, carbon monoxide $(\mathrm{CO})$ and hydrogen sulfide $\left(\mathrm{H}_{2} \mathrm{~S}\right)$, play a critical role in diverse physiological functions, including vascular tone, host defense against pathogens, neuromodulation, apoptosis, and energy metabolism in mammalian cells [1]. Among these gaseous molecules, $\mathrm{H}_{2} \mathrm{~S}$ is produced during amino acid metabolism by the trans-sulfuration and cysteine desulfuration pathways [2]. Endogenous $\mathrm{H}_{2} \mathrm{~S}$ production is catalyzed by three enzymes, cystathionine beta synthase (CBS), cystathionase (CTH) also known as cystathionine gamma-lyase, and 3-mercaptopyruvate sulfurtransferase (MST) [3-5].

$\mathrm{H}_{2} \mathrm{~S}$ functions as a stimulator of cellular bioenergetics, contributes to the increased reliance of cancer cells on the glycolytic pathway for ATP production and promotes angiogenesis and cytoprotection [6-8]. $\mathrm{H}_{2} \mathrm{~S}$ protects cells from oxidative stress [9], it can affect cellular responses to injury $[10,11]$ and was shown to exhibit both pro-apoptotic and anti-apoptotic effects [12-14].
Although some suggested that $\mathrm{H}_{2} \mathrm{~S}$ has anti-cancer effects [15], others reported that it promotes proliferation of HCT116 and SW480 colonic cancer cells [16]. Fu et al. showed that $\mathrm{Ca}^{2+}$ stimulation causes increased CTH expression and increases $\mathrm{H}_{2} \mathrm{~S}$ and ATP production [17]. It was shown that endogenous $\mathrm{H}_{2} \mathrm{~S}$ production driven by 3 -MST complements and balances the cellular bioenergetics and maintains electron flow in mitochondria [18]. Colonic cancer cells have been shown to exhibit up-regulated expression of CBS and increased formation of $\mathrm{H}_{2} \mathrm{~S}$, which directs cell proliferation and angiogenesis in colon cancer [6].

It is known that tumor cells can recover from potential lethal damage induced by hypoxia, acidosis, or by radiation and drug treatment [19-22]. We recently reported that cancer cells that recover from damages induced by hypoxia, acidosis and glucose deprivation show mitochondrial remodeling, increased aerobic glycolysis, and exhibit a high rate of ATP production [23]. In this study, we explore the role of $\mathrm{H}_{2} \mathrm{~S}$ in the process of recovery of cancer cells from damage. Damaged cancer cells exhaust their 
energy supply due to repair mechanisms. Both ATP and $\mathrm{NAD}^{+}$ (Nicotinamide adenine dinucleotide) are the main energy sources. Nicotinamide phosphoribosyltransferase (Nampt), an enzyme required for NAD synthetic salvage pathway [24], is vital to the maintenance of cellular energy supply. Therefore, we examined the role of Nampt in conjunction with $\mathrm{H}_{2} \mathrm{~S}$ in cancer cells that recover from damage. We demonstrate that $\mathrm{H}_{2} \mathrm{~S}$ controls the recovery of cancer cells from damage by regulating Nampt directed change in energy expenditure, which drives adoption of aerobic glycolysis and increase in ATP and $\mathrm{NAD}^{+}$synthesis. The interaction of $\mathrm{H}_{2} \mathrm{~S}$ and Nampt confers the cancer cells a high proliferation rate and a high degree of tolerance to damage.

\section{Materials and Methods}

\section{Materials}

$\mathrm{H}_{2} \mathrm{O}_{2}$, NaHS, bleomycin, $\mathrm{O}$-(carboxymethyl) hydroxylamine hemihydrochloride $(\mathrm{CHH})$ DL-propargylglycine $(\mathrm{PAG})$ and FK866 were purchased from Sigma-Aldrich (St. Louis, MO). Antibodies against CBS (A-2), CTH (G-1) and $\beta$-Actin (C-2) were purchased from Santa Cruz Biotechnology (Santa Cruz, CA). Antibodies against Nampt (Visfatin, PBEF) and Bax were purchased from Abcam (Cambridge, MA). Antibody against $\gamma$ H2AX was purchased from Millipore (Billerica, MA). Secondary antibodies conjugated to horseradish peroxidase were purchased from Jackson ImmunoResearch Laboratories (Baltimore, PA).

\section{Cell culture}

HepG2, MDA-MB-231 and MDA-MB-435S were obtained from ATCG (Manassas, VA) cultured in DMEM with $2 \mathrm{mM}$ glutamine, $25 \mathrm{mM}$ glucose and $10 \%$ fetal bovine serum, in $37^{\circ} \mathrm{C}$ incubator with $5 \% \mathrm{CO}_{2}$. Damage was induced in cancer cells by hypoxia, glucose deprivation and hydrogen peroxide. For induction of hypoxia $\left(\mathrm{DR}^{\mathrm{H}}\right)$, cells were incubated for $18 \mathrm{hr}$ in $1 \% \mathrm{O}_{2}$. For glucose deprivation $\left(\mathrm{DR}^{\mathrm{G}-}\right)$, cells were cultured for $18 \mathrm{hr}$ in a medium without glucose in presence of $5 \% \mathrm{CO}_{2}$. For induction of damage by hydrogen peroxide $\left(\mathrm{DR}^{\mathrm{H} 2 \mathrm{O} 2}\right)$, cells were treated with $800 \mu \mathrm{M} \mathrm{H} \mathrm{H}_{2} \mathrm{O}_{2}$ for $3 \mathrm{hr}$.

\section{Animal experiments}

Animal care and all procedures were carried out following approval of the Institutional Animal Care Committees of University of California, Irvine (protocol \#2012-3042). Eightweek-old athymic nude $(\mathrm{Nu} / \mathrm{Nu})$ male mice $(\mathrm{n}=10)$ were purchased from Charles River Laboratories (San Diego, CA). Mice were anesthetized by inhalation of Isoflurane before injection of tumor cells. Each mouse received $1 \times 10^{5}$ tumor cells in a total volume of $100 \mu \mathrm{l}$ subcutaneously in four locations in the midabdominal and lower flank areas. Mice were monitored 2 times per week during tumor growth experiment. Twenty days after injection of cells, mice were euthanized by carbon dioxide inhalation when tumors grew to the size of $10-15 \mathrm{~mm}$ in diameter. Tumors were removed for isolation of viable cancer cells $\left(\mathrm{T}^{\mathrm{V}}\right)$ or damage recovered cells from in vivo grown tumor $\left(\mathrm{T}^{\mathrm{DR}}\right)$.

\section{Measurement of $\mathrm{H}_{2} \mathrm{~S}$ production in extra and intra-cells}

Measurement of extracellular $\mathrm{H}_{2} \mathrm{~S}$ level was performed using Free Radical Analyzer (TBR4100 and ISO-H2S-2, World Precision Instruments, Sarasota, FL) following manufacturer's instruction. Briefly, cell number was adjusted to $1 \times 10^{6}$ viable cells in PBS and the cell suspensions were incubated at $37^{\circ} \mathrm{C}$ for $1 \mathrm{hr}$. Cells were then centrifuged and the supernatants were subjected to measurements. Prior to each measurement, the sensor was polarized and calibrated by adding four aliquots of the $\mathrm{Na}_{2} \mathrm{~S}$ stock solution at the final concentrations of $0.25,0.5,1.0$ and $2.0 \mu \mathrm{M}$. Detection of intracellular $\mathrm{H}_{2} \mathrm{~S}$ was performed by $\mathrm{H}_{2} \mathrm{~S}$ fluorescent probe HSN2 (a kind gift from Professor Michael D. Pluth, University of Oregon, Department of Chemistry, Eugene, Oregon).

\section{Whole cell protein extraction and Western blotting}

Proteins from cells were extracted in lysis buffer $(50 \mathrm{mM}$ Tris$\mathrm{HCl}, \mathrm{pH} 7.5,150 \mathrm{mM} \mathrm{NaCl}, 1 \% \mathrm{NP}-40,2 \mathrm{mM}$ EDTA, $1 \mathrm{mM}$ PMSF, $1 \mathrm{mM} \mathrm{Na} \mathrm{VO}_{4}, 50 \mathrm{mM} \mathrm{NaF}$, and protease inhibitor cocktail). Protein measurements were carried out by Bio-Rad protein assay based on Bradford dye-binding method (Bio-Rad Lab, Hercules, CA).

Blotting bands were detected by ECL enhanced chemiluminescence (Amersham ECL Plus Western Blotting Detection Reagents GE Healthcare Life Sciences, Pittsburgh, PA) using C-Digit Digital Imager (LI-COR, Lincoln, NE) and densitometric analysis was performed using myImage Analysis software (Thermo Scientific). $\beta$-actin served as a loading control.

\section{Cell viability measurement}

Relative cell number was measured by XTT assay (SigmaAldrich, St. Louis, MO). Cells were incubated with XTT and phenazine methosulfate (PMS) at $37^{\circ} \mathrm{C}$ for $2 \mathrm{hr}$ and absorbance was read at 450 and $650 \mathrm{~nm}$ as a reference.

\section{Reverse transcription-Polymerase chain reaction (PCR) and Quantitative PCR (qPCR)}

Total RNA was isolated using GenElute Mammalian Total RNA Miniprep Kit (Si $\gamma$ ma-Aldrich, St. Louis, MO). Reverse transcription was performed using High-Capacity cDNA Reverse Transcription Kit (Applied Biosystems, Carlsbad, CA). RT-PCR was carried out using the primers specific for the human CBS (forward: GAACGAGACGGAGCAGACAA; reverse: GTCGCTCAGGAACTTGGTCA), for the human CTH (forward: AAAGACGCGTCGTCACAAGG; reverse: AAGGCAATTCGTAGTGGGATTTG) and for the human MTS (forward: CGGCGTGTCACTGCTTGAT; reverse: CAGGTTCAATGCGGTCTCG). Gene expression was assessed by PCR using Taq $5 \times$ Master Mix (New England Biolabs. Ipswich, MA) with an initial denaturation step $94^{\circ} \mathrm{C}$ for $5 \mathrm{~min}$, followed by 30 cycles with each at $94^{\circ} \mathrm{C}$ for $30 \mathrm{sec}, 55^{\circ} \mathrm{C}$ for $30 \mathrm{sec}$, and $68^{\circ} \mathrm{C}$ for $1 \mathrm{~min}$.

Quantitative evaluation was performed by using myImage Analysis software (Thermo Scientific, New Hampshire). For normalization of data, $\beta$-ACTIN was amplified with specific primers (forward: AAGCGACGCCACTTCTCTCT; reverse: GAGACCAAAAGCCTTCATACATCT). qPCR was performed using Quanti Tect SYBR Green PGR Kit. qPGR was carried out using the primers specific for the human NAMPT (forward: ATC CTG TTG CAG GGT ATT CTG; reverse: CCG CAT ATT TTG TGA GAC GCA T).

\section{XF (extracellular flux) bioenergetic analysis}

XF24 Extracellular Flux Analyzer from Seahorse Bioscience (N. Billerica, MA) was utilized for extracellular fluid bioenergetic analysis [25]. Under typical in vitro cell culture conditions, extracellular acidification rate (ECAR) is contributed by lactic acid production generated by glycolysis. To examine the aerobic glycolysis, five biological replicate cultures of control $\left(3 \times 10^{4}\right)$ and five independently generated DR cells $\left(3 \times 10^{4}\right)$ were plated in each well of the XF 24 culture plate and cells were incubated overnight at $37^{\circ} \mathrm{C}$ in presence of $5 \% \mathrm{CO}_{2}$. All cultures were examined in 
XFAssay media in the absence of $\mathrm{CO}_{2}$. Level of ECAR was normalized to the protein content.

\section{Quantitation of Nampt, ATP and NAD ${ }^{+} / \mathrm{NADH}$}

Intracellular Nampt levels were measured using a Visfatin Gterminal (Human) EIA kit (Phoenix pharmaceuticals, Belmont, CA, USA). ATP levels in cells was assayed using the Bioluminescent ATP Somatic cell assay kit (FLASC, Sigma-Aldrich company) and colorimetric ATP assay kit (Abcam, Cambridge, MA) according to manufacturer's instruction. $\mathrm{NAD}^{+} / \mathrm{NADH}$ levels were measured using $\mathrm{NAD}^{+} / \mathrm{NADH}$ assay kit (Cayman Chemical Company, Ann Arbor, Michigan and Bio Assay Systems, Hayward CA) following manufacturer's instruction. Levels of Nampt, ATP and $\mathrm{NAD}^{+} / \mathrm{NADH}$ were normalized to the protein content.

\section{Statistics}

All assays were done in 3-6 replicates in at least three independent experiments. Data are shown as mean \pm SEM (standard error of the mean). $p$ values were determined by comparing the data from experimental versus control cells from at least three independent experiments or six replicates of the same experiment. Means and $p$ values for experimental data were analyzed by subjecting the data to the two tailed t-test. Data involving more than two groups were accessed by one-way ANOVA with Bonferroni's test for post hoc analysis. $p$ values less than 0.05 were considered significant. $p$ Values are shown as $<0.05^{(*)},<0.005^{(* *)}$ or $<0.0005^{(* * *)}$.

\section{Results}

\section{The generation of $\mathrm{H}_{2} \mathrm{~S}$ increases in response to stress}

In contrast to previous reports in which $\mathrm{H}_{2} \mathrm{~S}$ has been measured in cell lysate, we utilized $\mathrm{H}_{2} \mathrm{~S}$-sensitive electrode to measure the release of $\mathrm{H}_{2} \mathrm{~S}$ from intact cells. We found that the amount of $\mathrm{H}_{2} \mathrm{~S}$ released from cells was significantly higher than that measured in homogenized cell extracts (data not shown). In comparison with the levels of $\mathrm{H}_{2} \mathrm{~S}$ released from 293 cells and fibroblasts, cancer cells (HepG2, MDA-MB-231, MDA-MB-435S) produced significantly more $\mathrm{H}_{2} \mathrm{~S}$ (Figure 1A). We subjected epithelial cancer cells of different origins (liver, breast, and melanocyte) to harsh conditions that exist in the tumor microenvironment, which all lead to cell damage including hypoxia $\left.{ }^{\mathrm{H}}\right)$, glucose deprivation $\left({ }^{\mathrm{G}-}\right)$ and hydrogen peroxide $\left({ }^{\mathrm{H} 2 \mathrm{O} 2}\right)$. The $\mathrm{H}_{2} \mathrm{~S}$ generation was increased in cancer cells in response to acute stress such as hypoxia, bleomycin, hydrogen peroxide and glucose deprivation (Figure 1B). Stress related rise in $\mathrm{H}_{2} \mathrm{~S}$ released from cancer cells was associated with increase in cystathionine beta synthase (CBS), one of the enzymes that drives $\mathrm{H}_{2} \mathrm{~S}$ production, concomitant with increase in stress and apoptosis-related $\mathrm{Bax}$ and $\gamma \mathrm{H} 2 \mathrm{AX}$, which is a critical factor of the $\mathrm{S} / \mathrm{G}_{2}$ DNA-damage checkpoint complex (Figure 1C, D). Interestingly, stress induced elevation in $\mathrm{H}_{2} \mathrm{~S}$ production correlated with the severity of damage (Figure 1E).

\section{The increased generation of $\mathrm{H}_{2} \mathrm{~S}$ in damage-recovered cells increases tolerance to damage}

The scheme in Figure 2A shows the method that we used to generate the damage recovered cancer cells. Within $24 \mathrm{hr}$ after damage, few viable cells remained attached to the culture flask while majority of cells detached from culture surface. Damaged detached cells exhibit a high level of $\mathrm{H}_{2} \mathrm{~S}$ likely to limit the injury and can improve survival potential (Figure S1). To remove the mitotic cells, we cultured cells in new culture vessels for $24 \mathrm{hr}$. To isolate damaged cells that failed to bind to culture vessels but had the potential to recover from damage, we transferred floating cells to new culture vessels to allow cells that recover from damage to bind to the culture substrates. Serial weekly passages of floating cells to new culture vessels allowed isolation of damage recovered cells with different recovery time. Throughout this paper, we refer to these cells as damage-recovered (DR) cells with indicated recovery time of one $\left(\mathrm{DR}^{\mathrm{W} 1}\right)$, two $\left(\mathrm{DR}^{\mathrm{W} 2}\right)$ or three weeks $\left(\mathrm{DR}{ }^{\mathrm{W} 3}\right)$ from damage, while we refer to the parental control cells as Pc cells (Figure 2A). This method enabled us to separate three populations of cells that reflect the length of time required for recovery. In order to assess whether isolated DR cells recovered from damage, we examined the expression of pro-apoptotic molecule, Bax. DR cells showed a decrease in Bax expression in a recovery time dependent manner as an indication of repair, while as predicted, Pc cells exposed to $\mathrm{H}_{2} \mathrm{O}_{2}$ for $3 \mathrm{hr}$ (acute damage) expressed a high level of Bax (Figure 2B). Furthermore, cancer cells recovered from damage also exhibited an increased production of $\mathrm{H}_{2} \mathrm{~S}$ as compared to the undamaged $\mathrm{Pc}$ cells in a recovery time dependent manner (Figure 2C, D). Since endogenous hydrogen sulfide is generated by three enzymes, CBS, CTH and MST, we examined mRNA and protein levels of these enzymes in Pc and DR cells. As shown in Figure 2E, mRNA levels of CBS and CTH increased in DR cells also in a recovery time dependent manner. However, MST was absent in Pc or DR cells. As compared to parental undamaged Pc cells, cancer cells recovered from damage had increased CBS and CTH proteins in direct correlation with the recovery period. Among the DR cells, those cells with a longer recovery time from damage show the highest up-regulation of CBS and CTH (Figure 2F). CBS was up-regulated up to 2 fold after recovery from damage induced by glucose deprivation, hypoxia and hydrogen peroxide (Figure 2G). As compared to Pc cells, DR cells generating higher levels of $\mathrm{H}_{2} \mathrm{~S}$ had a higher proliferation rate and showed a higher level of tolerance to damage induced by bleomycin (Figure 2H, I). These findings show that in cells recovered from damage, $\mathrm{H}_{2} \mathrm{~S}$ production might play a role in their increased tolerance to damage.

\section{DR cells exhibit increased glycolysis and enhanced cellular bioenergetics}

Because rapidly dividing cells adopt aerobic glycolysis to promote an increased biomass followed by cell division, we examined the level of key glycolytic intermediates and enzymes in cells recovered from damage. DR cells showed an elevated extracellular acidification rate (ECAR), which is an indicator of level of glycolysis (Figure 3A). DR cells generating high levels of $\mathrm{H}_{2} \mathrm{~S}$ had a better bioenergetic profile as evidenced by increased level of cellular ATP (Figure 3B).

In order to address whether suppression of glycolysis attenuates $\mathrm{H}_{2} \mathrm{~S}$ production, we measured $\mathrm{H}_{2} \mathrm{~S}$ level in DR cells treated with HKl inhibitor, $100 \mu \mathrm{M}$ bromopyruvic acid, or LDH-A inhibitor, $1 \mathrm{mM}$ sodium oxamate, for $15 \mathrm{hr}$. As shown in Figure S2, there was no statistically significant difference in the level of $\mathrm{H}_{2} \mathrm{~S}$ after treatment with either bromopyruvic acid or sodium oxamate, whereas, as expected, glycolytic activity was substantially diminished by both inhibitors. These data indicate that glycolytic enzymes do not regulate $\mathrm{H}_{2} \mathrm{~S}-\mathrm{Nampt}$ circuit.

Cells recovered from damage heavily relied on glycolysis that increased demand for NADH/ $\mathrm{NAD}^{+}$. Therefore, as a measure of the bioenergetic state, we evaluated the levels of $\mathrm{NAD}^{+}$and $\mathrm{NADH}$. Although acute damage led to a decrease in the level of $\mathrm{NAD}^{+}, \mathrm{NAD}^{+}$was significantly increased in cancer cells that recovered from damage induced by $\mathrm{H}_{2} \mathrm{O}_{2}$ and hypoxia (Figure $3 \mathrm{C}$, D; Figure S3). Reduced form of $\mathrm{NAD}^{+}, \mathrm{NADH}$, was significantly increased in DR cells (Figure S4). 
A

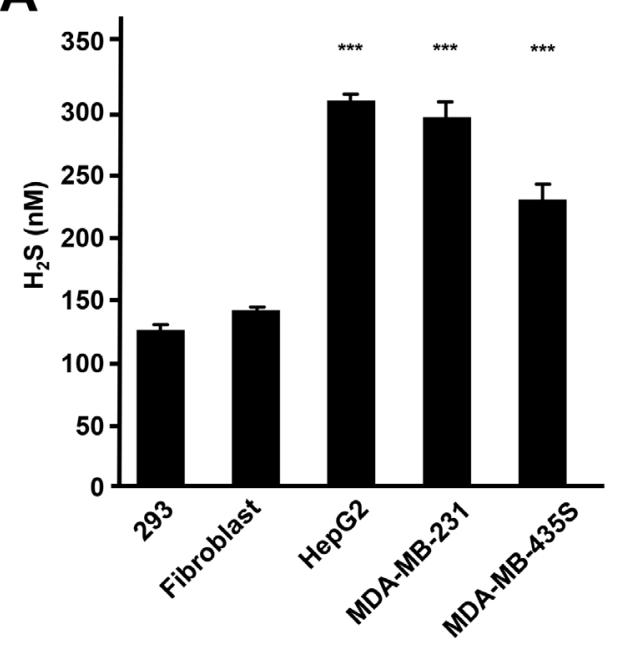

C

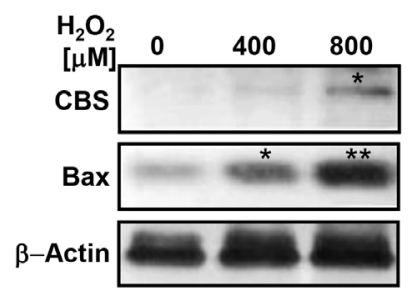

E

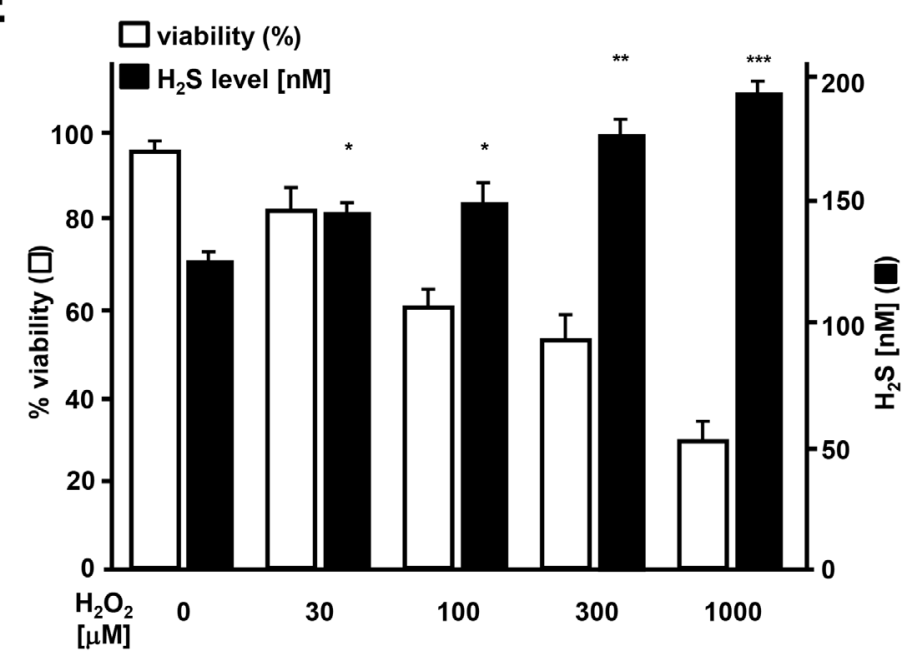

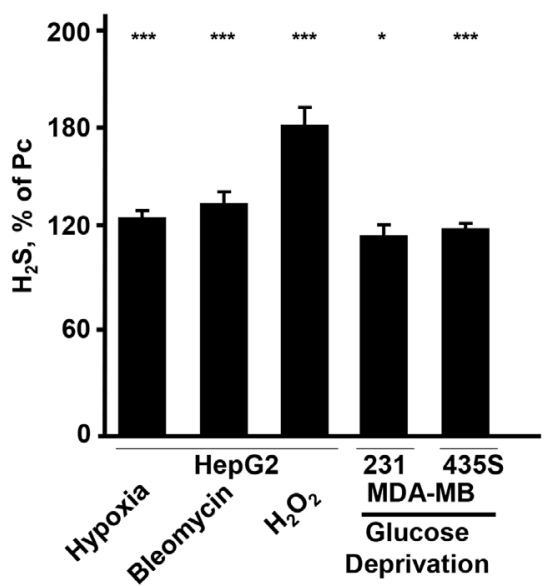

D $\square$ CBS

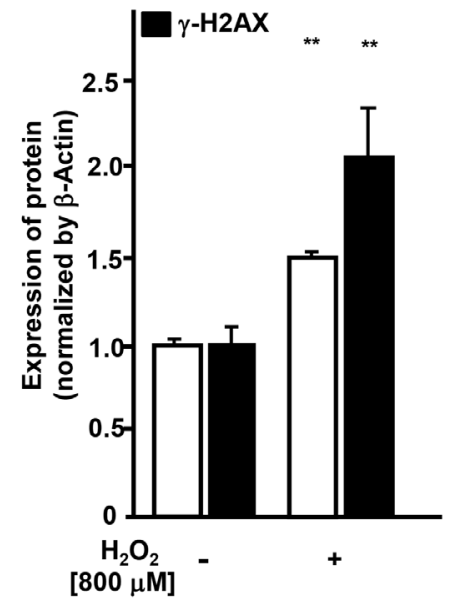

Figure 1. Endogenous hydrogen sulfide increases in response to acute damage in cancer cells. (A) $A m o u n t$ of $\mathrm{H}_{2} \mathrm{~S}$ released by 293 cells, fibroblasts (Fibro.), HepG2, MDA-MB-231 and MDA-MB-435S cells. (B) The levels of $\mathrm{H}_{2} \mathrm{~S}$ in HepG2, MDA-MB-231 and MDA-MB-435S Pc cells subjected to hypoxia $\left(0.5 \% \mathrm{O}_{2}, 18 \mathrm{hr}\right.$ ), glucose deprivation (glucose free medium, $18 \mathrm{hr}$ ) or treatment with bleomycin (35 $\mathrm{nM}, 18 \mathrm{hr}$ ), $\mathrm{H}_{2} \mathrm{O}_{2}(800 \mu \mathrm{M}, 3 \mathrm{hr})$. Data are expressed as percent of $\mathrm{H}_{2} \mathrm{~S}$ released from untreated cells. (C) Intracellular CBS and Bax (left panel) assessed by western blot analysis in MDA-MB435S Pc cells, and Pc cells treated with 400 or $800 \mu \mathrm{M}$ of $\mathrm{H}_{2} \mathrm{O}_{2}$ for $3 \mathrm{hr}$. (D) The level of CBS and $\gamma \mathrm{H}_{2} \mathrm{AX}$ with or without treatment with $\mathrm{H}_{2} \mathrm{O}_{2}$ ( $800 \mu \mathrm{M}$, $3 \mathrm{hr}$ ) in MDA-MB-435S cells. Protein density was normalized using $\beta$-Actin. (E) Amount of $\mathrm{H}_{2} \mathrm{~S}$ and cell viability after treatment with a range of concentration of $\mathrm{H}_{2} \mathrm{O}_{2} .{ }^{*} ; p<0.05,{ }^{* *} ; p<0.005$, ${ }^{* * *} ; p<0.0005$.

doi:10.1371/journal.pone.0108537.g001 
A

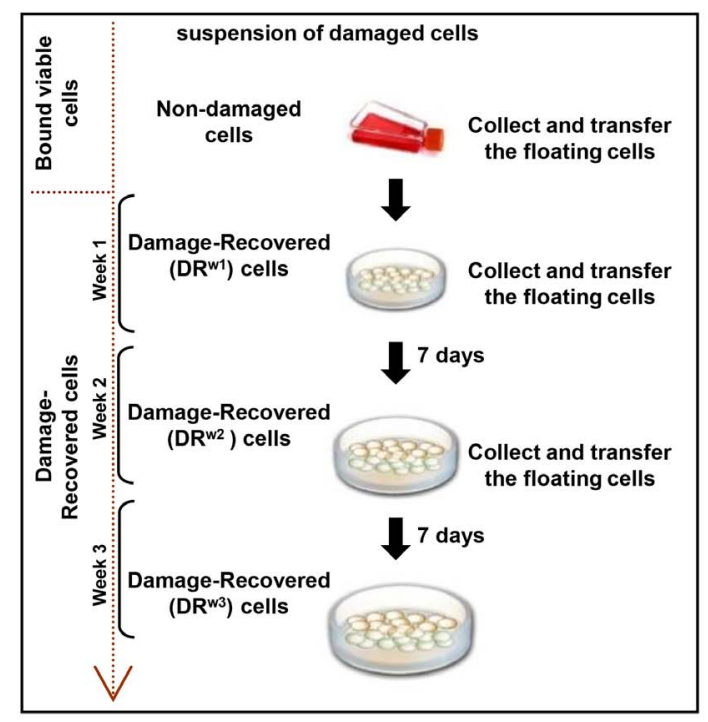

B

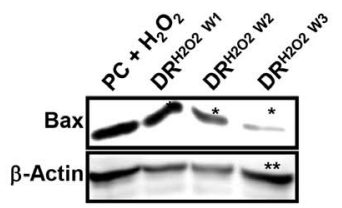

D

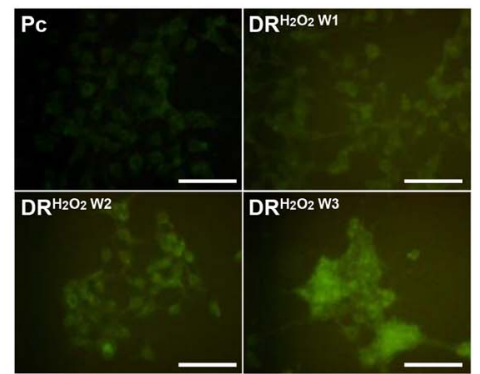

C

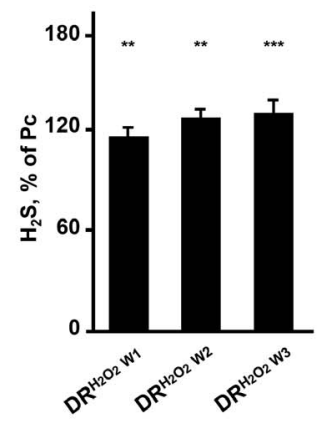

E

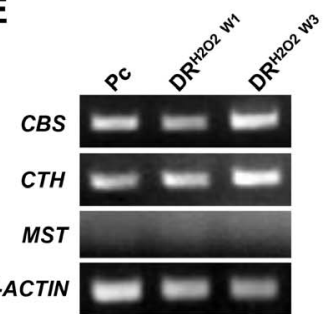

$\mathbf{F}$

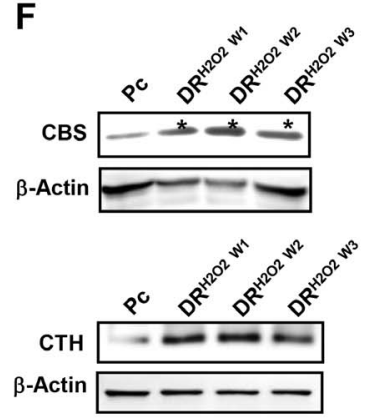

G

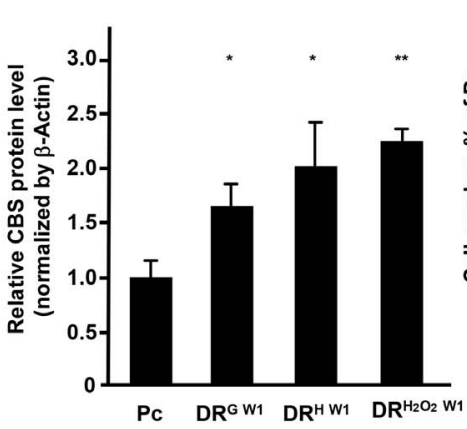

H

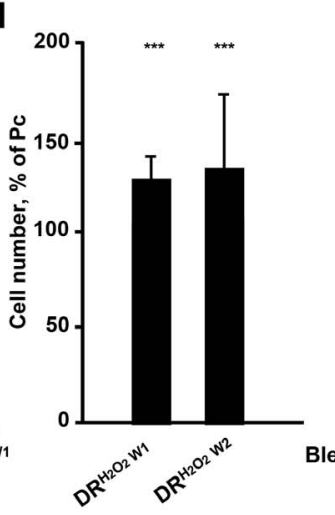

I

Figure 2. Damage-Recovered (DR) cells show increase in $\mathbf{H}_{2} \mathrm{~S}$ and proliferation rate and exhibit tolerance to damage. (A) $A$ scheme for isolation of Damage-Recovered (DR) cells. (B) Bax expression in $\mathrm{H}_{2} \mathrm{O}_{2}$ treated $\mathrm{Pc}, \mathrm{DR}^{\mathrm{H} 2 \mathrm{O} 2} \mathrm{~W}^{1}, \mathrm{DR}^{\mathrm{H} 2 \mathrm{O} 2} \mathrm{~W}_{2}$ and DR ${ }^{\mathrm{H} 2 \mathrm{O} 2}$ w3 $\mathrm{HepG} 2$ cells. (C) Amount of $\mathrm{H}_{2} \mathrm{~S}$ released by $\mathrm{DR}^{\mathrm{H} 2 \mathrm{O} 2 \mathrm{~W} 1}, \mathrm{DR}^{\mathrm{H} 2 \mathrm{O} 2 \mathrm{~W} 2}$ and $\mathrm{DR}^{\mathrm{H} 2 \mathrm{O} 2} \mathrm{~W}_{3}$ HepG2 cells. Significance between Pc and three DR cells was $p<0.0005$ in ANOVA statistical analysis. (D) $\mathrm{H}_{2} \mathrm{~S}$ staining of $\mathrm{PC}, \mathrm{DR}^{\mathrm{H} 2 \mathrm{O} 2} \mathrm{~W} 1, \mathrm{DR}^{\mathrm{H} 2 \mathrm{O} 2} \mathrm{~W} 2$ and $\mathrm{DR}^{\mathrm{H} 2 \mathrm{O} 2} \mathrm{~W}_{3} \mathrm{HepG} 2$ cells with $5 \mu \mathrm{M} \mathrm{H} \mathrm{H}_{2} \mathrm{~S}$ fluorescent probe, HSN2. Scale bars, $50 \mu \mathrm{m}$. (E) PCR analysis of CBS, CTH and MTS genes in Pc, DR ${ }^{\mathrm{H} 2 \mathrm{O} 2} \mathrm{w}_{1}$ and $\mathrm{DR}^{\mathrm{H} 2 \mathrm{O} 2} \mathrm{w}_{3} \mathrm{HepG} 2$ cells. (F) Western blot analysis of CBS and CTH in Pc, DR ${ }^{\mathrm{H} 2 \mathrm{O} 2}$ W1, DR ${ }^{\mathrm{H} 2 \mathrm{O} 2} \mathrm{~W}_{2}$ and $\mathrm{DR}^{\mathrm{H} 2 \mathrm{O} 2} \mathrm{~W}_{3} \mathrm{HepG} 2$ cells. (G) Western blot analysis of CBS in PC and DR ${ }^{\mathrm{H} 2 \mathrm{O} 2} \mathrm{~W}_{1}, \mathrm{DR}^{\mathrm{H}} \mathrm{W}^{\mathrm{W}}$ and $\mathrm{DR} \mathrm{R}^{\mathrm{G} 1} \mathrm{HepG} 2$ cells. (H) Proliferation of HepG2 recovered from $\mathrm{H}_{2} \mathrm{O}_{2}, \mathrm{DR}^{\mathrm{H} 2 \mathrm{O} 2} \mathrm{~W} 1, \mathrm{DR}^{\mathrm{H} 2 \mathrm{O} 2}$ W2 cells as a percentage of that in Pc cells. (I) Viability of Pc, DR ${ }^{\mathrm{H} 2 \mathrm{O} 2} \mathrm{~W}^{2}$ and DR ${ }^{\mathrm{H} 2 \mathrm{O} 2}$ w2 HepG2 cells with and without treatment with bleomycin. ${ }^{*} ; p<0.05,{ }^{* *} ; p<0.005,{ }^{* * *} ; p<0.0005$.

doi:10.1371/journal.pone.0108537.g002

Nampt, which is required for $\mathrm{NAD}^{+}$synthetic salvage pathway [24], was significantly increased upon recovery in DR cells and this increase coincided with up-regulation of $\mathrm{H}_{2} \mathrm{~S}$ generating $\mathrm{CBS}$ (Figure 3E). The DR cells with longer recovery time from damage showed the highest increase in Nampt (Figure 3F). Moreover, we found that Nampt levels correlated with both the level of $\mathrm{H}_{2} \mathrm{~S}$ released from cells $\left(\mathrm{R}^{2}=0.9, p<0.05\right)$ and the intracellular level of $\operatorname{ATP}\left(\mathrm{R}^{2}=0.94, p<0.05\right)$ (Figure $\left.3 \mathrm{G}\right)$.

Together, these findings show that cancer cells recovered from damage generate a high level of $\mathrm{H}_{2} \mathrm{~S}$ and Nampt, and that they are heavily dependent on the production of $\mathrm{H}_{2} \mathrm{~S}$ and aerobic glycolysis for their efficient metabolism.
$\mathrm{H}_{2} \mathrm{~S}$, in a dose-dependent manner, up-regulates Nampt, increases aerobic glycolysis and affords cytoprotection

To further assess the importance of $\mathrm{H}_{2} \mathrm{~S}$ in acquisition of new metabolic characteristics, $\mathrm{Pc}$ cells were treated with $\mathrm{H}_{2} \mathrm{~S}$ donor, NaHS. Similar to our observations in DR cells (Figure 3A), treatment with NaHS enhanced ECAR in a dose dependent manner, increased $\mathrm{ATP}$ and $\mathrm{NAD}^{+}$output and led to significant rise in the level of Nampt (Figure 4A-F). Consistent with previous reports showing that $\mathrm{H}_{2} \mathrm{~S}$ provides cytoprotection [8,26], Pc cells pre-treated with NaHS exhibited a higher resistance to damage induced by either hydrogen peroxide or bleomycin (Figure 4G). 
A

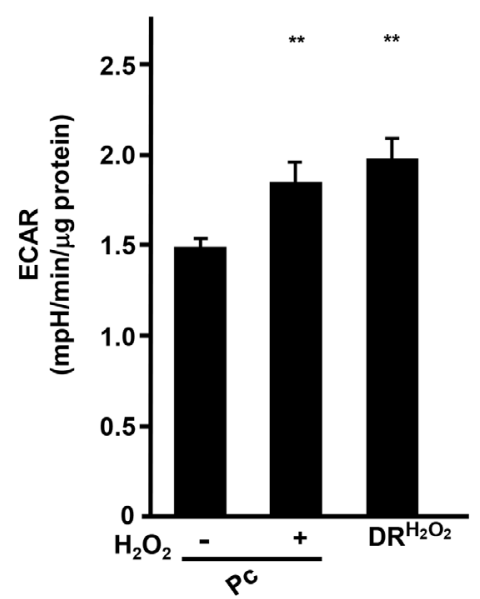

C

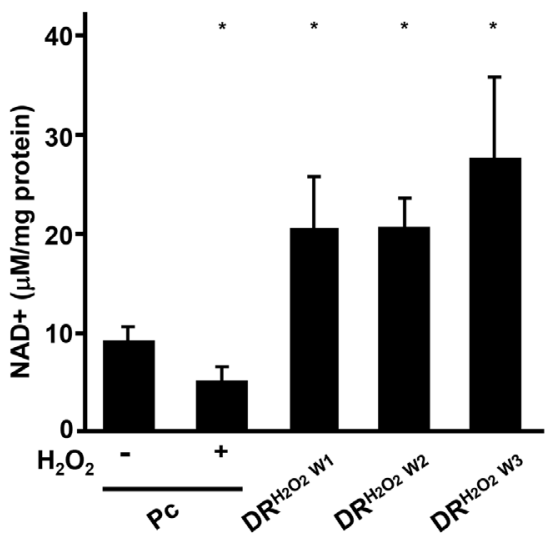

$\mathbf{F}$

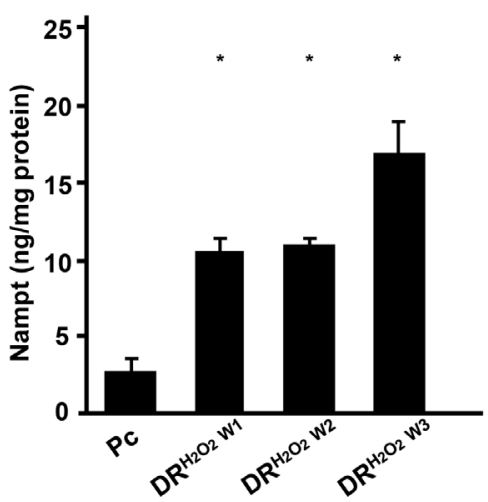

B

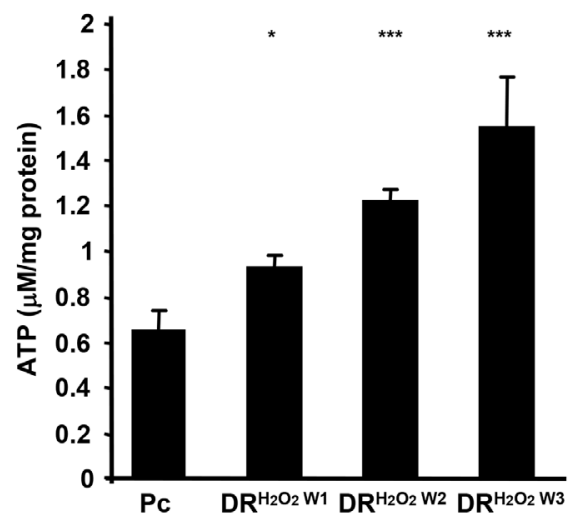

D

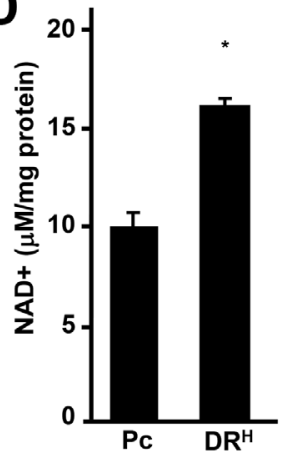

E

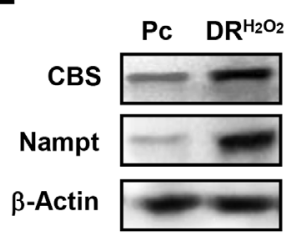

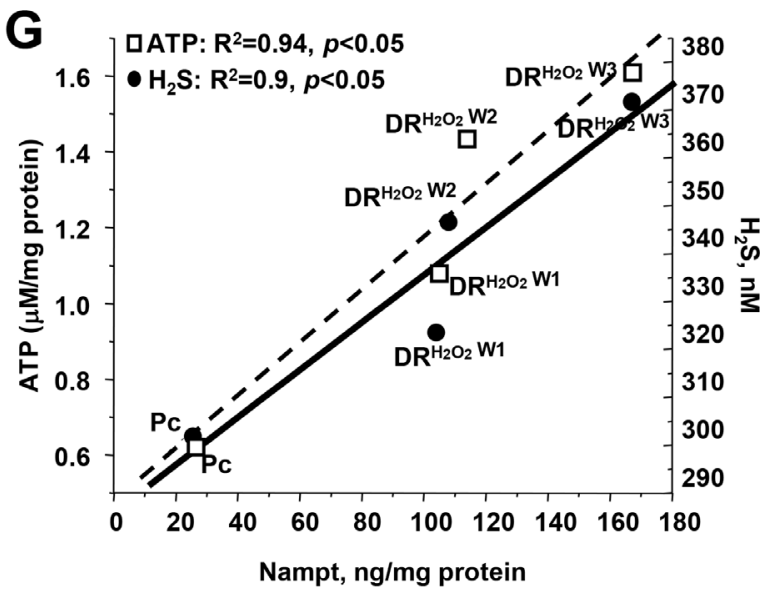

Figure 3. Changes in glycolysis and bioenergetics in DR cells. (A) ECAR in Pc HepG2 cells treated with or without $800 \mu \mathrm{M}$ of $\mathrm{H}_{2} \mathrm{O}_{2}$ and DR $\mathrm{H}^{\mathrm{H}} \mathrm{O} 2$ W2 HepG2 cells. (B) ATP levels in Pc, DR ${ }^{\mathrm{H} 2 \mathrm{O} 2}$ W1, $\mathrm{DR}^{\mathrm{H} 2 \mathrm{O} 2}$ w2 and $\mathrm{DR}^{\mathrm{H} 2 \mathrm{O} 2} \mathrm{~W} 3 \mathrm{HepG} 2$ cells. Significance between Pc and three DR cells was $p<0.005$ in

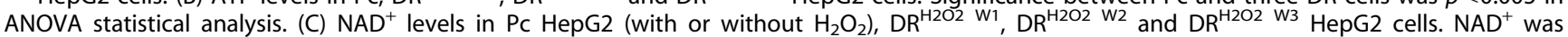
normalized to the level of total protein. Significance between Pc and there DR cells was $p<0.005$ in ANOVA statistical analysis. (D) NAD ${ }^{+}$levels in Pc and DR ${ }^{\mathrm{H} \text { W1 }}$ HepG2 cells. (E) Western blot analysis of intracellular Nampt and CBS in Pc and DR ${ }^{\mathrm{H} 2 \mathrm{O} 2}$ MDA-MB-231 cells. (F) Nampt levels assessed by ELISA in $\mathrm{Pc}, \mathrm{DR}^{\mathrm{H} 2 \mathrm{O} 2} \mathrm{~W} 1, \mathrm{DR}^{\mathrm{H} 2 \mathrm{O} 2} \mathrm{~W} 2$ and $\mathrm{DR}^{\mathrm{H} 2 \mathrm{O} 2}$ W3 $\mathrm{HepG} 2$ cells. Significance between Pc and three DR cells was $p<0.05$ in ANOVA statistical analysis. (G) Correlation between Nampt expression and production of $\mathrm{H}_{2} \mathrm{~S}$ and level of ATP in Pc, DR ${ }^{\mathrm{H} 2 \mathrm{O} 2} \mathrm{~W} 1, \mathrm{DR}^{\mathrm{H} 2 \mathrm{O} 2} \mathrm{~W}_{2}$ and $\mathrm{DR}^{\mathrm{H} 2 \mathrm{O} 2} \mathrm{~W}_{3} \mathrm{HepG}_{2}$ cells. Significance of $\mathrm{H}_{2} \mathrm{~S}$ and Nampt was $p<0.05$, and significance of ATP and Nampt was $p<0.05$ in ANOVA statistical analysis. ${ }^{*} ; p<0.05$, ${ }^{* *} ; p<0.005,{ }^{* * *}$; $p<0.0005$.

doi:10.1371/journal.pone.0108537.g003 
A

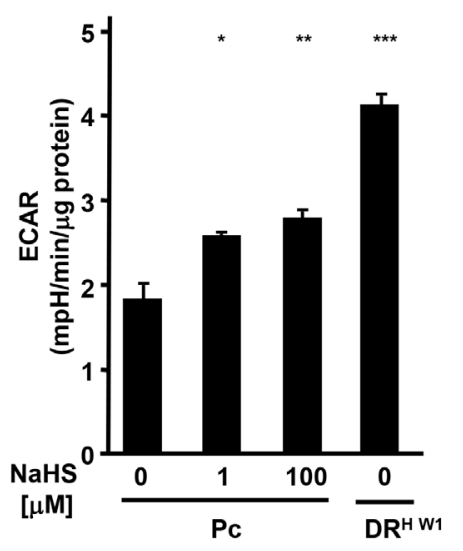

B

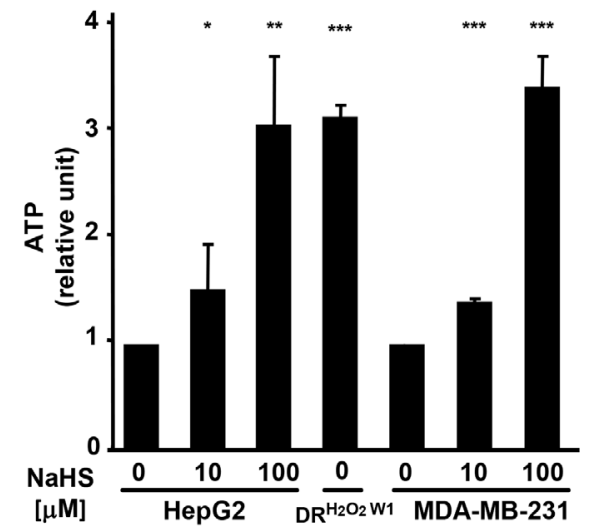

E

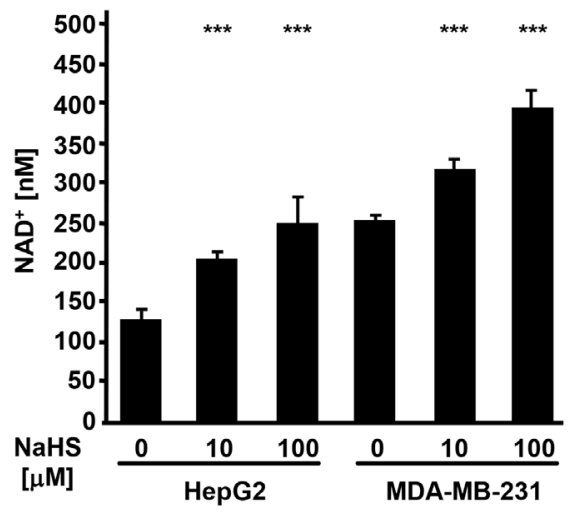

$\mathbf{F}$

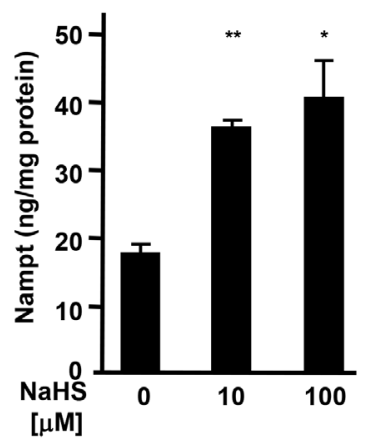

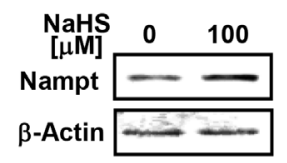

D $\beta$-Actin $=$

\section{G}

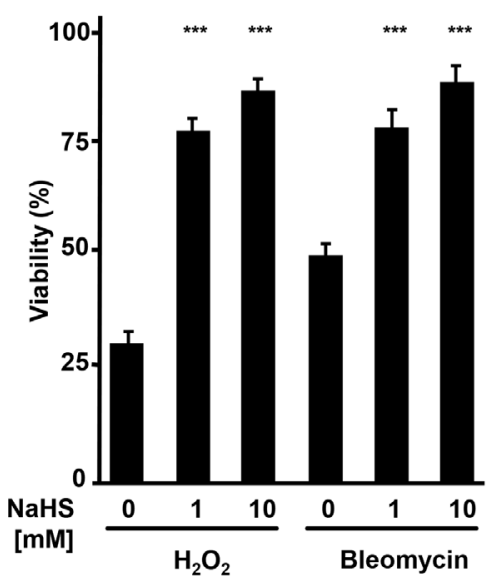

Figure 4. $\mathbf{H}_{\mathbf{2}} \mathbf{S}$ increases ECAR, ATP, NAD and Nampt in a dose-dependent manner in cancer cells. (A) ECAR in Pc HepG2 cells treated for $48 \mathrm{hr}$ with 0,1 , and $100 \mu \mathrm{M}$ of NaHS and DR ${ }^{\mathrm{H} 1} \mathrm{HepG} 2$ cells. (B) Comparison of ATP levels in Pc HepG2 cells treated for 48 hr with 0,10 and $100 \mu \mathrm{M}$ of NaHS, DR ${ }^{\mathrm{H} 2 \mathrm{O} 2 \mathrm{~W} 1}$ HepG2 cells and Pc MDA-MB-231 cells treated for $48 \mathrm{hr}$ with 0,10 and $100 \mu \mathrm{M}$ of NaHS. Data are expressed as a percent of level of ATP in untreated cells. (C) Levels of NAD ${ }^{+}$in HepG2 and MDA-MB-231 Pc cells treated with 0,10 , and $100 \mu \mathrm{M}$ of NaHS for 48 hr. (D) Western blot analysis of intracellular Nampt in MDA-MB-231 Pc cells treated for $48 \mathrm{hr}$ with 0 and $100 \mu \mathrm{M}$ of NaHS. (E) qPCR analysis of NAMPT expression in Pc HepG2 cells treated for $48 \mathrm{hr}$ with 0 and $100 \mu \mathrm{M}$ of NaHS. (F) Quantitation of intracellular Nampt by ELISA in Pc HepG2 cells treated for 48 hr with 0 , 10 and $100 \mu \mathrm{M}$ of NaHS. (G) Viability in HepG2 cells pre-treated for $24 \mathrm{hr}$ with 0,1 , and $10 \mathrm{mM}$ of NaHS and then subjected to $\mathrm{H}_{2} \mathrm{O}_{2}(800 \mu \mathrm{M})$ or bleomycin (35 nM, $18 \mathrm{hr}$ ). Viability was assessed by Trypan blue exclusion. ${ }^{*} ; p<0.05,{ }^{* *} ; p<0.005,{ }^{* * *} ; p<0.0005$. doi:10.1371/journal.pone.0108537.g004

Together, our findings show that up-regulation of $\mathrm{H}_{2} \mathrm{~S}$ and Nampt leading to glycolysis and bioenergetic changes are important mechanisms in the development of drug resistance and survival of cancer cells.
$\mathrm{H}_{2} \mathrm{~S}-$ Nampt pathway regulates bioenergetics in DR cells To further address the relation between Nampt and $\mathrm{H}_{2} \mathrm{~S}$ production, DR cells were treated with an inhibitor of Nampt, FK866. Treatment of cells with 200 nM of FK866 did not affect 
A

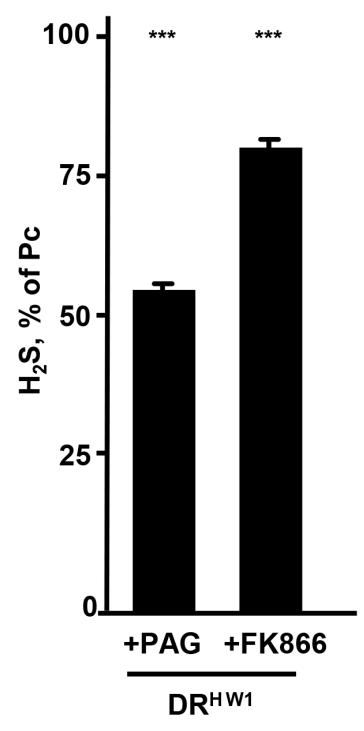

C

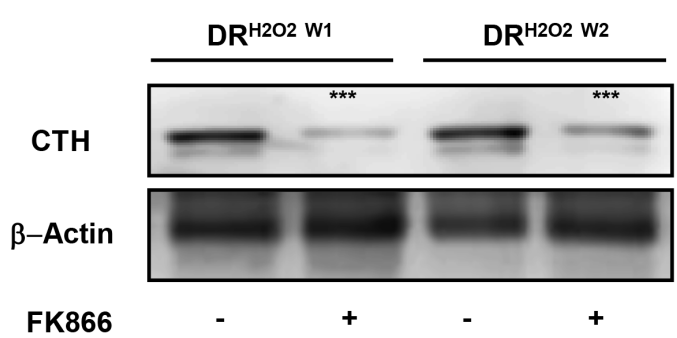

E

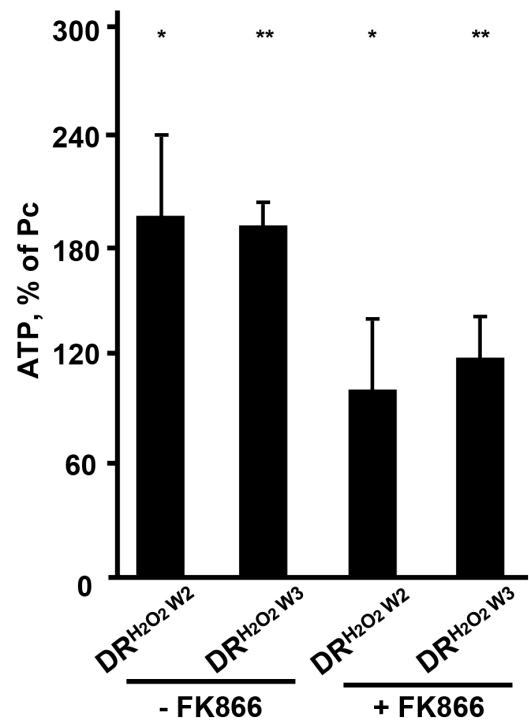

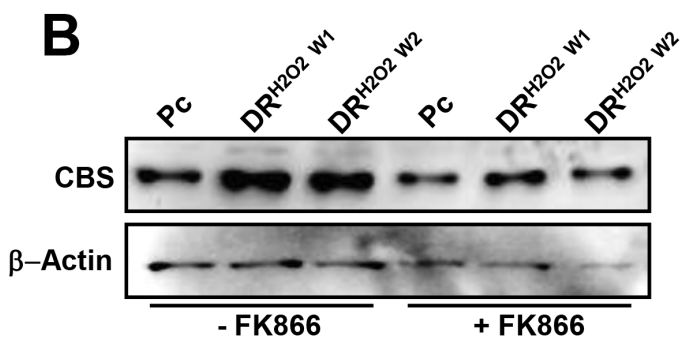

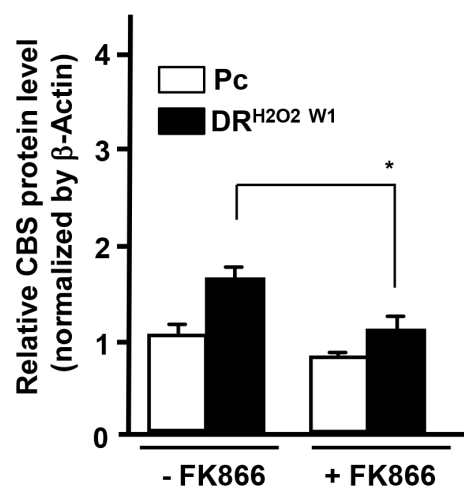

D

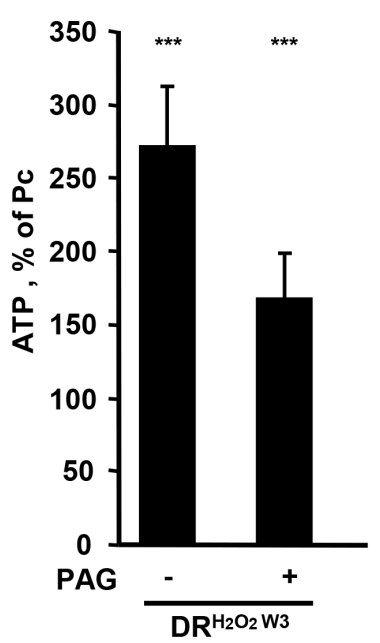

$\mathbf{F}$

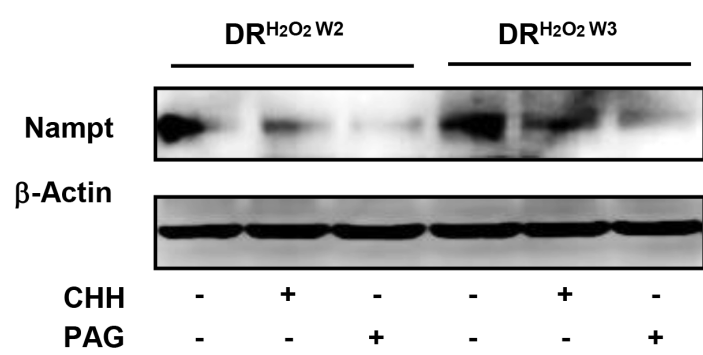


Figure 5. $\mathrm{H}_{2} \mathrm{~S}$-Nampt pathway regulates bioenergetics. (A) Amount of $\mathrm{H}_{2} \mathrm{~S}$ released from $\mathrm{DR}^{\mathrm{H} W 1} \mathrm{HepG} 2$ cells treated with CTH inhibitor, $\mathrm{PAG}$ $(100 \mu \mathrm{M}, 18 \mathrm{hr})$, and Nampt inhibitor, FK866 (200 nM, $24 \mathrm{hr})$. (B) Western blot analysis of CBS in DR cells in the absence and presence of FK866

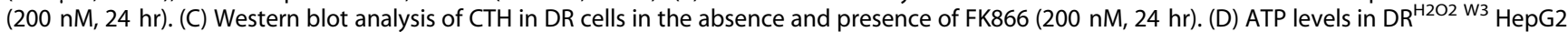
cells in the absence $(-)$ and presence $(+)$ of PAG $(100 \mu \mathrm{M}, 18 \mathrm{hr})$. (E) ATP levels in PC, DR ${ }^{\mathrm{H} 2 \mathrm{O} 2} \mathrm{~W}_{2}$ and $\mathrm{DR}^{\mathrm{H} 2 \mathrm{O} 2} \mathrm{~W} 3 \mathrm{HepG} 2$ cells in the absence and presence of FK866 (200 nM, $24 \mathrm{hr}$ ). (F) Western blot analysis of Nampt in $\mathrm{DR}^{\mathrm{H} 2 \mathrm{O} 2}$ W2 and DR ${ }^{\mathrm{H} 2 \mathrm{O} 2} \mathrm{~W}^{3} \mathrm{HepG} 2$ cells treated with CBS inhibitor, CHH $(500 \mu \mathrm{M}, 18 \mathrm{hr})$ or CTH inhibitor, PAG $(100 \mu \mathrm{M}, 18 \mathrm{hr}) .{ }^{*} ; p<0.05,{ }^{* * *} ; p<0.005,{ }^{* * *} ; p<0.0005$. doi:10.1371/journal.pone.0108537.g005

cell viability indicating the absence of FK866 cytotoxicity at this dose in HepG2 (Figure S5). Suppression of Nampt by its inhibitor, FK866, as well as inhibition of CTH by D, L-propargylglycine (PAG), led to decreased $\mathrm{H}_{2} \mathrm{~S}$ production (Figure 5A). Consistent with such a change in $\mathrm{H}_{2} \mathrm{~S}$ production, the expression of both CBS and CTH was attenuated by treatment of cells with FK866 (Figure 5B, C). The level of ATP was also significantly decreased by treatment of DR cells with PAG and FK866 (Figure 5D, E). This reduction of ATP was consistent with previous study showing that inhibition of Nampt by FK866 suppressed the production of ATP in ovarian cancer cells [27]. Interestingly, treatment of DR cells with inhibitor of CBS $(\mathrm{CHH})$ and inhibitor of CTH (PAG) reduced Nampt (Figure 5F). These data suggest that Nampt may function as a stimulator of $\mathrm{H}_{2} \mathrm{~S}$-producting enzymes and thereby production of $\mathrm{H}_{2} \mathrm{~S}$, whereas $\mathrm{H}_{2} \mathrm{~S}$ causes up-regulation of Nampt.

Taken together, our findings show that up-regulation of $\mathrm{H}_{2} \mathrm{~S}$ and Nampt and their crosstalk improve bioenergetic efficiency and facilitate recovery from damage.

\section{Accumulation of $\mathrm{H}_{2} \mathrm{~S}$ leads to higher glycolysis, better bioenergetics and increased proliferation in damage recovered cancer cells isolated from in vivo grown tumors}

To identify whether cells similar to in vitro generated DR cells exist or can be generated in tumors, epithelial cancer cells were inoculated into athymic nude mice. We isolated viable cancer cells $\left(\mathrm{T}^{\mathrm{V}}\right)$ and damage recovered $\left(\mathrm{T}^{\mathrm{DR}}\right)$ cells, as described in our previous study [23]. $\mathrm{T}^{\mathrm{DR}}$ cells isolated from in vivo generated tumors showed the accumulation of $\mathrm{H}_{2} \mathrm{~S}$ as well as increased expression of CBS and CTH (Figure 6A, B). Similar to in vitro data, the levels of $\mathrm{NAD}^{+}$and Nampt were increased in $\mathrm{T}^{\mathrm{DR}}$ cells as compared to the levels detected in $\mathrm{Pc}$ and $\mathrm{T}^{\mathrm{V}}$ cells (Figure $6 \mathrm{C}$, $\mathrm{D})$. ECAR was increased in $\mathrm{T}^{\mathrm{DR}}$ cells and these cells showed a better bioenergetic profile as evidenced by increased level of ATP and a higher proliferation rate (Figure $6 \mathrm{E}-\mathrm{G}$ ).

Based on these findings, we propose a scheme whereby cancer cells recovered from damage change their metabolic profile via upregulation of $\mathrm{H}_{2} \mathrm{~S}-\mathrm{Nampt}$ pathway (Figure $6 \mathrm{H}$ ). Thus, $\mathrm{H}_{2} \mathrm{~S}-$ Nampt dependent energetic circuit is a critical regulator of stress tolerance, increased glycolysis, improved bioenergetics and increased cell proliferation.

\section{Discussion}

The endogenous production of $\mathrm{H}_{2} \mathrm{~S}$ is highly upregulated in epithelial colorectal and prostate cancer cells, and in tumorderived endothelial cells [28,29]. In line with this evidence, we show that epithelial cancer cells (liver, breast, skin) innately produce large amounts of hydrogen sulfide independent of their origin. $\mathrm{H}_{2} \mathrm{~S}$ is increased even further in cancer cells upon acute damage induced by hypoxia, hydrogen peroxide and bleomycin, or following recovery from damage as a result of increased expression of $\mathrm{H}_{2} \mathrm{~S}$-producing enzymes, $C B S$ and $C T H$. These data are consistent with observations reported by others that $C T H$ expression is upregulated by hypoxia leading to increased production of $\mathrm{H}_{2} \mathrm{~S}$ [17].
$\mathrm{H}_{2} \mathrm{~S}$ has been reported to have cytoprotective effects against hydrogen peroxide and doxorubicin induced toxicity and hypoxia [30-33]. We show here that DR cancer cells that recover from damage demonstrate cross tolerance to damaging conditions that induce death in a high number of parental control cancer cells. Moreover, when Pc cells are treated with NaHS, the cells develop resistance to damage. Together, our data suggest that an increase in $\mathrm{H}_{2} \mathrm{~S}$ can occur in response to damage regardless of cell type or mode of damage. Based on such evidence, we suggest that increased $\mathrm{H}_{2} \mathrm{~S}$ may be significant in the recovery of cancer cells from damages (e.g., oxidative stress, hypoxia, glucose deprivation, acidosis) that these cells endure in the harsh tumor microenvironments.

$\mathrm{H}_{2} \mathrm{~S}$ is also essential to an increased proliferation in cancer cells recovered from damage. Consistent with our data, Cai et al. showed that treatment of HCT116 and SW480 colonic cancer cells with NaHS increased cell proliferation in these cancer cells [16]. The increase was dependent on Akt and ERK phosphorylation and blockade of Akt and ERK activation attenuated NaHS-induced cell proliferation. However contrary to such an observation, Jurkoska et al. showed that treatment of human neuroblastoma SH-SY5Y cells with NAC and ribose-cysteine, which results in elevation of hydrogen sulfide, leads to inhibition of cancer cell proliferation [34]. Furthermore, Cao et al. reported that treatment of WiDr colonic epithelial cancer cells with 50 to $200 \mu \mathrm{M}$ NaHS for $24 \mathrm{hr}$ suppresses viability [35]. One possible explanation for such paradoxical results may be attributed to sensitivity of certain cancer cells towards hydrogen sulfide mediated changes in the redox state. Another possibility is that this might be due to the fact that the effects of $\mathrm{H}_{2} \mathrm{~S}$ are dose dependent. Thus, we show that $\mathrm{H}_{2} \mathrm{~S}$, in a dose-dependent manner, up-regulates Nampt, increases aerobic glycolysis and provides cytoprotection.

We show that in cancer cells that exhibit a high level of $\mathrm{H}_{2} \mathrm{~S}$, aerobic glycolysis and level of $\mathrm{ATP}$ and $\mathrm{NAD}^{+}$are coordinately increased. We further show that such an increase in level of ATP and $\mathrm{NAD}^{+}$in damage survivors is due to up-regulation of $\mathrm{H}_{2} \mathrm{~S}$ production since forced increase in intracellular level of $\mathrm{H}_{2} \mathrm{~S}$ leads to a concomitant rise in cellular pool of ATP and $\mathrm{NAD}^{+}$. In line with these observations, $\mathrm{H}_{2} \mathrm{~S}$ is shown to improve mitochondrial ATP production following hypoxia [17]. Increased generation of $\mathrm{H}_{2} \mathrm{~S}$ plays an important role in dictating cell survival after severe damage by promoting a reduction-oxidation balance, suppressing oxidative stress in mitochondria and increasing glutathione production [36].

We show that regardless of the type of injury, cancer cells that recover from damage show increased reliance on glycolysis as a main source of energy. Synthesis of ATP depends on the content of $\mathrm{NAD}^{+}$. Under glycolytic conditions, cells regenerate $\mathrm{NAD}^{+}$via one of the recycling pathways; by either converting pyruvate into lactate or recycling nicotinamide (NAM) to NAD [37]. As shown here, the cyto-protective effects of $\mathrm{H}_{2} \mathrm{~S}$ is related to its ability to increase cellular pool of ATP and $\mathrm{NAD}^{+}$through a Nampt mediated response. Cancer cells, which are treated with $\mathrm{H}_{2} \mathrm{~S}$ donor, NaHS, and cancer cells, which recover from damage, show an increased CBS and CTH driven $\mathrm{H}_{2} \mathrm{~S}$ synthesis, and increased 


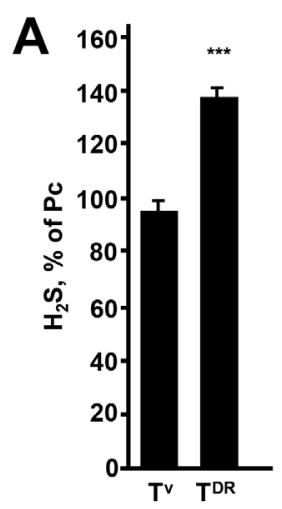

D

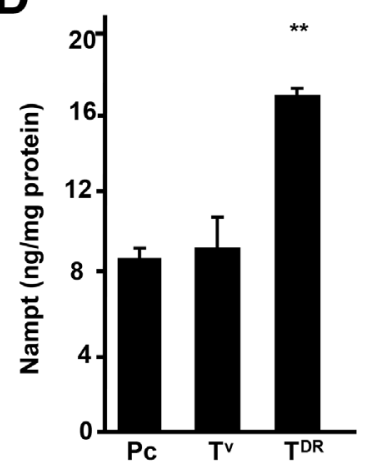

G

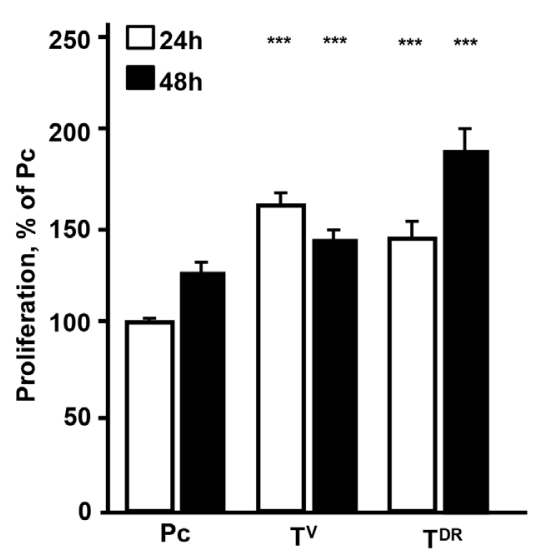

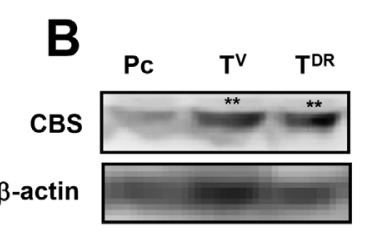
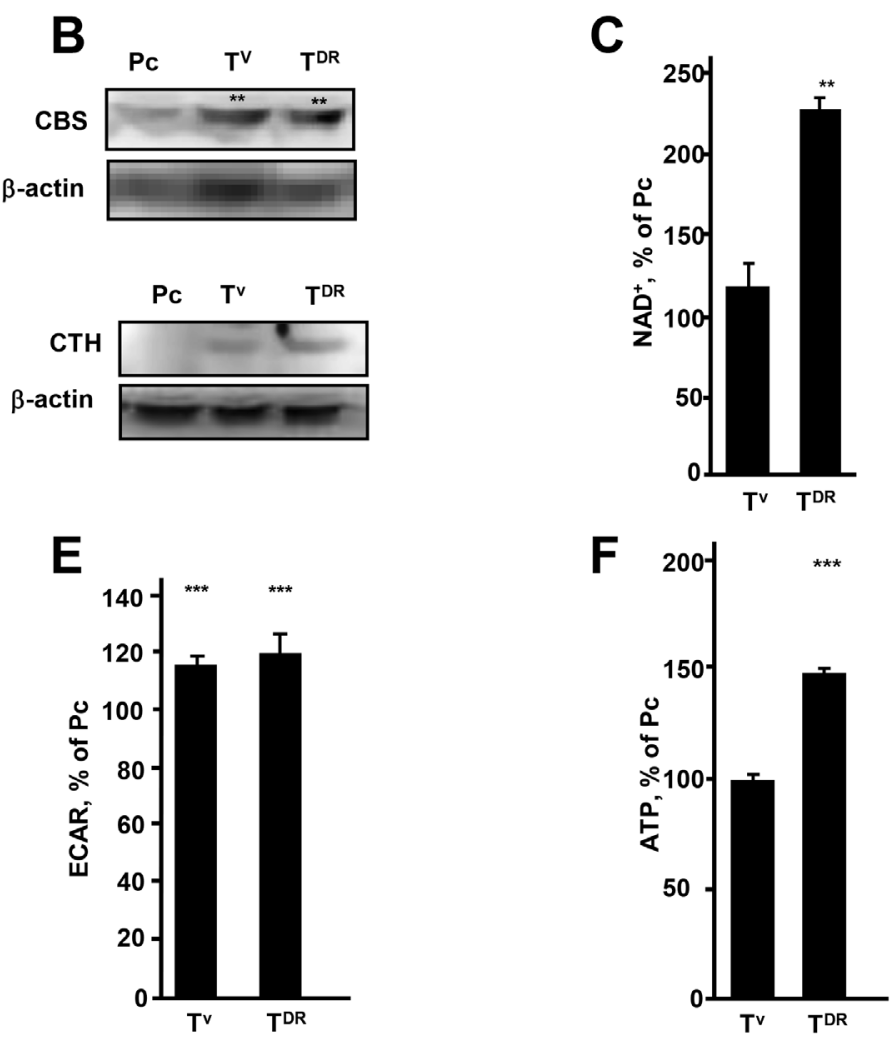

H

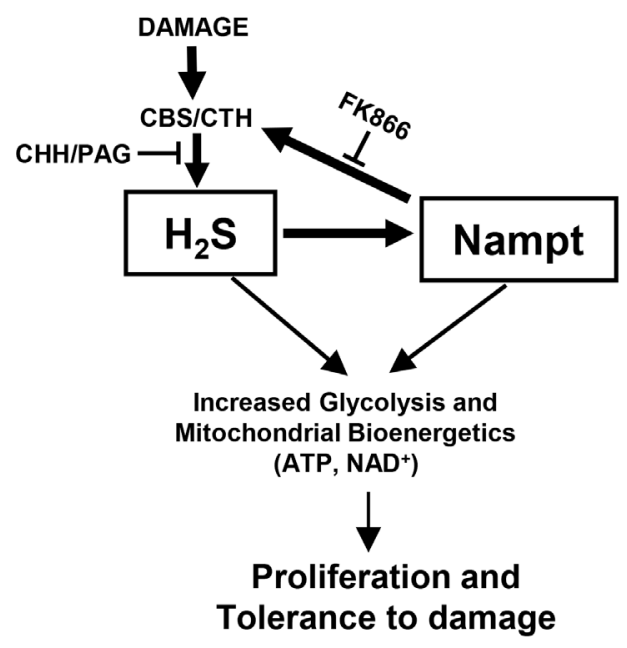

Figure 6. $\mathbf{H}_{2} \mathrm{~S}$ levels and bioenergetic changes in DR cells isolated from tumors. (A) $\mathrm{H}_{2} \mathrm{~S}$ levels in $T^{\mathrm{V}}$ and $\mathrm{T}^{\mathrm{DR}}$ cells isolated from HepG2 tumors grown in vivo. (B) Expression of CBS and CTH in $\mathrm{T}^{\mathrm{V}}$ and $\mathrm{T}^{\mathrm{DR}}$ cells. (C) NAD levels in $\mathrm{T}^{\mathrm{V}}$ and $\mathrm{T}^{\mathrm{DR}}$ cells isolated from HepG2 tumors grown in vivo. (D) Nampt levels in $T^{V}$ and $T^{D R}$ cells isolated from HepG2 tumors grown in vivo. (E) ECAR in $T^{V}$ and $T^{D R}$ cells isolated from HepG2 tumors grown in vivo expressed as the percent of the ECAR level in Pc. (F) ATP level in viable tumor cells ( $\mathrm{T}^{\mathrm{V}}$ ) isolated from HepG2 tumors grown in vivo expressed as the percent of the ATP level in Pc. (G) Proliferation of $T^{V}$ and $T^{D R}$ cells isolated from HepG2 tumors grown in vivo expressed as the percent of the proliferation of Pc. Cells were seeded at a concentration of $2 \times 10^{4}$ and the total number of cells was assessed after 24 and $48 \mathrm{hr}$ of culture. (H) A scheme for $\mathrm{H}_{2} \mathrm{~S}$-Nampt dependent bioenergetic circuit. Cell damage leads to increased $\mathrm{H}_{2} \mathrm{~S}$ and Nampt that coordinately lead to metabolic changes. These cells exhibit exponential growth and tolerance to damage. ${ }^{*} ; p<0.05,{ }^{* *} ; p<0.005,{ }^{* * *} ; p<0.0005$.

doi:10.1371/journal.pone.0108537.g006

Nampt, the rate-limiting factor in $\mathrm{NAD}^{+}$biosynthesis, and its product $\mathrm{NAD}^{+}$. Such changes should enable cells to survive when supplies of ATP and $\mathrm{NAD}^{+}$are exhausted. Another possibility to consider is that, some, if not all of the increase in ATP in cancer cells, might be due to the direct utilization of $\mathrm{H}_{2} \mathrm{~S}$ as a substrate in
ATP generation by cancer cells. Recent evidence suggests that, in mammalian cells, $\mathrm{H}_{2} \mathrm{~S}$ can serve as an electron donor and an inorganic source of energy. While low concentrations of $\mathrm{H}_{2} \mathrm{~S}(0.1-$ $1 \mu \mathrm{M})$ elicit a significant increase in mitochondrial function, its higher concentrations $(3-30 \mu \mathrm{M})$ have an opposite effect on 
cellular bioenergetics [18]. Based on such data, it has been suggested that intra-mitochondrial $\mathrm{H}_{2} \mathrm{~S}$ complements and balances the bioenergetic role of Krebs cycle-derived electron donors. Consistent with these observations, our data show that accumulation of $\mathrm{H}_{2} \mathrm{~S}$ and upregulation of Nampt contribute to glycolytic activity, whereas glycolytic inhibitors were ineffective towards $\mathrm{H}_{2} \mathrm{~S}$ and Nampt implying that $\mathrm{H}_{2} \mathrm{~S}-\mathrm{Nampt}$ is the leading cause of changes associated with adoption of glycolysis.

Our data show that FK866, a highly specific non-competitive inhibitor of Nampt, reduces expression of $\mathrm{H}_{2} \mathrm{~S}$-producing enzymes, diminishes production of $\mathrm{H}_{2} \mathrm{~S}$, and leads to depletion of ATP in cancer cells that recover from damage. Consistent with our data, it has been shown that FK866 which depletes the cellular pool of $\mathrm{NAD}^{+}$, induces tumor cell apoptosis while nicotinic acid and nicotinamide (Vitamin B3) oppose such effects of FK866 [38]. FK866 causes attenuation of glycolysis at the glyceraldehyde 3phosphate dehydrogenase step which leads to restricted carbon flow from glycolysis resulting in reduced serine biosynthesis [27]. Therefore, FK866 mediated inhibition of $\mathrm{H}_{2} \mathrm{~S}$ production might be attributed to reduced biosynthesis of serine and its utilization by CBS, which produces $\mathrm{H}_{2} \mathrm{~S}$ and cystathionine. Cystathionine, in turn, is utilized by CTH to further produce $\mathrm{H}_{2} \mathrm{~S}$ and cysteine. The existence of this positive feedback loop between $\mathrm{H}_{2} \mathrm{~S}$ and Nampt may contribute to glycolytic activity and survival of cancer cells in face of microenvironmental challenges as well as after drug treatment. One of the downstream targets of Nampt is Sirtuin (Sirt1) that was reported to have impact on the survival mechanism [39]. Our preliminary data demonstrated that Sirtinol that acts as an inhibitor of Sirtl, did not affect the level of ATP in $\mathrm{H}_{2} \mathrm{O}_{2}$ treated control or DR cells (data not shown).

Consistent with the in vitro data, we show that damage recovered cancer cells derived from tumors generated in vivo exhibit a high level of $\mathrm{H}_{2} \mathrm{~S}$ and Nampt and concomitantly show increased glycolysis, $\mathrm{ATP}$ and $\mathrm{NAD}^{+}$production. According to Oncomine database, $\mathrm{H}_{2}$ S-producing enzymes, CBS, CTH and MST as well as Nampt are all overexpressed in cancers of liver and breast and in melanomas (https://www.oncomine.org/) suggesting that this pathway operates in cancer cells of diverse origin. Together, our finding suggests that most cancers rely on $\mathrm{H}_{2} \mathrm{~S}$ and Nampt to survive damages that they endure in their microenvironment.

In summary, a key attribute of cancer cells recovering from damage is accumulation of $\mathrm{H}_{2} \mathrm{~S}$ that enables their recovery via a Nampt mediated metabolic change. $\mathrm{H}_{2} \mathrm{~S}$-Nampt pathway is a driving force in acquisition of a glycolytic phenotype, exponential growth and tolerance to damage. Therefore, even a small subset of tumor cells that recover from damage can give rise to generation of resistant cells that contribute to the expansion of cancer cell pool and facilitate their adaptation to a new microenvironment.

\section{References}

1. Kajimura M, Fukuda R, Bateman RM, Yamamoto T, Suematsu M (2010) Interactions of Multiple Gas-Transducing Systems: Hallmarks and Uncertainties of $\mathrm{CO}, \mathrm{NO}$, and $\mathrm{H}_{2} \mathrm{~S}$ Gas Biology. Antioxid Redox Signal 13: 157-192.

2. Kamoun $P$ (2004) Endogenous production of hydrogen sulfide in mammals. Amino Acids 26: 243-54.

3. Kery V, Bukovska G, Kraus JP (1994) Transsulfuration depends on heme in addition to pyridoxal $5^{\prime}$-phosphate. Cystathionine beta-synthase is a heme protein. J Biol Chem 269: 25283-25288.

4. Yang G, Wu L, Jiang B, Yang W, Qi J, et al. (2008) $\mathrm{H}_{2} \mathrm{~S}$ as a physiologic vasorelaxant: hypertension in mice with deletion of cystathionine gamma-lyase. Science 322: 587-590.

5. Shibuya N, Tanaka M, Yoshida M, Ogasawara Y, Togawa T, et al. (2009) 3Mercaptopyruvate sulfurtransferase produces hydrogen sulfide and bound sulfane sulfur in the brain. Antioxid Redox Signal 11: 703-714.

6. Szabó C, Coletta C, Chao C, Módis K, Szczesny B, et al. (2013) Tumor-derived hydrogen sulfide, produced by cystathionine- $\beta$-synthase, stimulates bioenerget-

\section{Supporting Information}

Figure S1 Floating cells exhibit higher $\mathrm{H}_{2} \mathrm{~S}$ level compare to bound cells. HepG2 cells were treated with $800 \mu \mathrm{M}$ $\mathrm{H}_{2} \mathrm{O}_{2}$ for $3 \mathrm{hr}$, then floating or bound cells were collected for $\mathrm{H}_{2} \mathrm{~S}$ measurement. Mean values were compared to untreated control. $* * * ; p<0.0005$.

(TIF)

Figure S2 Levels of $\mathrm{H}_{2} \mathrm{~S}$ and $\mathrm{NAMPT}$ are not affected by glycolytic inhibitor. The $\mathrm{DR}^{\mathrm{H} 2 \mathrm{O} 2 \mathrm{~W} 2} \mathrm{HepG} 2$ cells were treated with HK1 inhibitor, $100 \mu \mathrm{M}$ Bromopyruvic Acid, or LDH-A inhibitor, $1 \mathrm{mM}$ Sodium Oxamate for $15 \mathrm{hr}$ and levels of $\mathrm{H}_{2} \mathrm{~S}(\mathrm{~A})$ or Lactic Acid (B) were measured. Lactic Acid was measured by pphenylphenol based colorimetric assay [40]. *; $p<0.05$, **; $p<$ 0.005. (G) NAMPT expression using Bromopyruvic Acid or Sodium Oxamate treated $\mathrm{DR}^{\mathrm{H} 2 \mathrm{O} 2} \mathrm{~W}^{\mathrm{W}} \mathrm{HepG} 2$ cells. $\beta$ - $A C T I N$ was used as a loading control.

(TIF)

Figure $\mathrm{S3} \mathrm{NAD}^{+}$level decreases upon $\mathrm{H}_{2} \mathrm{O}_{2}$ damage. HepG2 cells were treated with $800 \mu \mathrm{M} \mathrm{H}_{2} \mathrm{O}_{2}$ for $3 \mathrm{hr}$. NAD ${ }^{+}$ assay (A) was performed and Nampt expression (B) was measured by Western blotting. Mean values were normalized to total protein. $\beta$-actin served as a loading control. *; $p<0.05$.

(TIF)

Figure S4 Level of NADH is increased in $D^{\mathbf{H}}$ cells. Level of $\mathrm{NADH}$ was measured in $\mathrm{Pc}$ and $\mathrm{DR}^{\mathrm{H}} \mathrm{HepG} 2$ cells by $\mathrm{NAD}^{+}$/ NADH assay kit following manufacturer's instruction. Level of $\mathrm{NADH}$ was normalized to the protein content.

(TIF)

Figure S5 Viability of cancer cells treated with FK866. Pc and $\mathrm{DR}^{\mathrm{H} 2 \mathrm{O} 2 \mathrm{~W}^{\mathrm{W}} \mathrm{H}}$ HepG2 cells were treated with 0, 1, 10, 100 and $200 \mathrm{nM}$ with FK866 for $18 \mathrm{hr}$ and performed XTT assay. Data are expressed as percentage (\%) of control. There were no statistically significant changes in cell viability of cancer cells treated with any concentration of FK866.

(TIF)

\section{Acknowledgments}

We thank to Dr. Michael D. Pluth for a generous gift of $\mathrm{H}_{2} \mathrm{~S}$ probe, HSN2.

\section{Author Contributions}

Conceived and designed the experiments: RSA EO SA ST. Performed the experiments: RSA EO SA. Analyzed the data: RSA EO SA ST. Contributed reagents/materials/analysis tools: SG. Contributed to the writing of the manuscript: SG ST.

ics, cell proliferation, and angiogenesis in colon cancer. Proc Natl Acad Sci U S A 110: 12474-12479.

7. Papapetropoulos A, Pyrichou A, Altaany Z, Yang G, Marazioti A, et al. (2009) Hydrogen sulfide is an endogenous stimulator of angiogenesis. Proc Natl Acad Sci U S A 106: 21972-7.

8. Yang C, Yang Z, Zhang M, Dong Q, Wang X, et al. (2011) Hydrogen Sulfide Protects against Chemical Hypoxia-Induced Cytotoxicity and Inflammation in HaCaT Cells through Inhibition of ROS/NF-кB/COX-2 Pathway. PLoS One 6: e219711.

9. Kimura $\mathrm{Y}$, Kimura $\mathrm{H}$ (2004) $\mathrm{H}_{2} \mathrm{~S}$ protects neurons form oxidative stress. FASEB J 18: 1165-1167.

10. Elrod JW, Calvert JW, Morrison J, Doeller JE, Kraus DW, et al. (2007) Hydrogen sulfide attenuates myocardial ischemia-reperfusion injury by preservation of mitochondrial function. Proc Natl Acad Sci U S A 104: 15560-15565.

11. Szabó C (2007) Hydrogen sulfide and its therapeutic potential. Nat Rev Drug Discov 6: 917-935. 
12. Cao Y, Adhikari S, Ang AD, Moore PK, Bhatia M (2006) Mechanism of induction of pancreatic acinar cell apoptosis by Hydrogen sulfide. Am J Physiol Cell Physiol 291: C503-510.

13. Sivarajah A, Collino M, Yasin M, Benetti E, Gallicchio M, et al. (2009) Antiapoptotic and anti-inflammatory effects of hydrogen sulfide in a rat model of regional myocardial I/R. Shock 31: 267-274.

14. Basker R, Li L, Moore PK (2012) Hydrogen sulfide-induces DNA damage and changes in apoptotic gene expression in human lung fibroblast cells. FASEB J 21: 247-255.

15. Predmore BL, Lefer DJ, Gojon G (2012) Hydrogen sulfide in biochemistry and medicine. Antioxid Redox Signal 17: 119-140.

16. Cai WJ, Wang MJ, Ju LH, Wang C, Zhu YC (2010) Hydrogen sulfide induces human colon cancer cell proliferation: role of Akt, ERK and p21. Cell Biol Int 34: 565-572.

17. Fu M, Zhang W, Wu L, Yang G, Li H, et al. (2011) Hydrogen sulfide $\left(\mathrm{H}_{2} \mathrm{~S}\right)$ metabolism in mitochondria and its regulatory role in energy production. Proc Natl Acad Sci U S A 109: 2943-2948.

18. Módis K, Coletta C, Erdelyi K, Papapetropoulos A, Szabo C (2012) Intramitochondrial hydrogen sulfide production by 3-mercaptopyruvate sulfurtransferase maintains mitochondrial electron flow and supports cellular bioenergetics. FASEB J 27: 601-611.

19. Boucher Y, Baxter LT, Jain RK (1990) Interstitial Pressure Gradients in Tissueisolated and Subcutaneous Tumors: Implications for Therapy. Cancer Res 50: 4478-4484.

20. Varnes ME, Dethlefsen LA, Biaglow JE (1986) The effect of $\mathrm{pH}$ on potentially lethal damage recovery in A549 cells. Radiat Res 108: 80-90.

21. Heller DP, Raaphorst GP (1994) Inhibition of potentially lethal damage recovery by altered $\mathrm{pH}$, glucose utilization and proliferation in plateau growth phase human glioma cells. Int J Radiat Biol 66: 41-47.

22. Phillips RA, Tolmach IJ (1966) Repair of potentially lethal damage in $x-$ irradiated HeLa cells. Radiat Res 29: 413-431.

23. Akakura S, Ostrakhovitch E, Sanokawa-Akakura R, Tabibzadeh S (2014) Cancer cells recovering from damage exhibit mitochondrial restructuring and increased aerobic glycolysis. Biochem Biophys Res Commun 448: 461-466.

24. Rongvaux A, Shea RJ, Mulks MH, Gigot D, Urbain J, et al. (2002) Pre-B-cell colony-enhancing factor, whose expression is up-regulated in activated lymphocytes, is a nicotinamide phosphoribosyltransferase, a cytosolic enzyme involved in NAD biosynthesis. Eur J Immunol 32: 3225-3234.

25. Wu M, Neilson A, Swift AL, Moran R, Tamagnine J, et al. (2007) Multiparameter metabolicanalysis reveals a close link between attenuated mitchondial bioenergetics function and enhanced glycolysis dependency in human tumor cells. Am J Physiol Cell Physiol 292: C125-C136.
26. Lan A, Liao X, Mo L, Yang C, Yang Z, et al. (2011) Hydrogen sulfide protects against chemical hypoxia-induced injury by inhibiting ROS-activated ERK1/2 and p38MAPK signaling pathways in PC12 cells. PLoS One 6: e25921.

27. Tan B, Young DA, Lu ZH, Wang T, Meier TI, et al. (2013) Pharmacological inhibition of nicotinamide phosphoribosyltransferase (NAMPT), an enzyme essential for $\mathrm{NAD}^{+}$biosynthesis, in human cancer cells: metabolic basis and potential clinical implications. J Biol Chem 288: 3500-3511.

28. Guo H, Gai JW, Wang Y, Jin HF, Du JB, et al. (2012) Characterization of hydrogen sulfide and its synthases, cystathionine $\beta$-synthase and cystathionine $\gamma$ lyase, in human prostatic tissue and cells. Urology 79: 483.e1-5.

29. Pupo E, Pla AF, Avanzato D, Moccia F, Cruz JE, et al. (2011) Hydrogen sulfide promotes calcium signals and migration in tumor-derived endothelial cells. Free Radic Biol Med 51: 1765-1773.

30. Wen YD, Wang H, Kho SH, Rinkiko S, Sheng X, et al. (2013) Hydrogen sulfide protects HUVECs against hydrogen peroxide induced mitochondrial dysfunction and oxidative stress. PLoS One 8: e53147.

31. Shen Y, Guo W, Wang Z, Zhang Y, Zhong L, et al. (2013) Protective effects of hydrogen sulfide in hypoxic human umbilical vein endothelial cells: a possible mitochondria-dependent pathway. Int J Mol Sci 14:13093-130108.

32. Zhang Q, Yuan L, Liu D, Wang J, Wang S, et al. (2014) Hydrogen sulfide attenuates hypoxia-induced neurotoxicity through inhibiting microglial activation. Pharmacol Res S1043-6618: 00049-8.

33. Wang M, Guo Z, Wang S (2014) Regulation of cystathionine $\gamma$-lyase in mammalian cells by hypoxia. Biochem Genet 52: 29-37.

34. Jurkowaska H, Wrobel M (2008) N-acetyl-L cysteine as a source of sulfane sulfur in astrocytomaand astrocyte cultures: Correlations with cell proliferation. Amino Acids 34: 231-237.

35. Cao O, Zhang L, Yang G, Xu C, Wang R (2010) Butyrate-stimulated $\mathrm{H}_{2} \mathrm{~S}$ production in colon cancer cells. Antioxid Redox Signal 12: 1101-1109.

36. Kimura Y, Goto Y, Kimura H (2010) Hydrogen sulfide increases glutathione production and suppresses oxidative stress in mitochondria. Antioxid Redox Signal 12: 1-13.

37. Garten A, Petzold S, Körner A, Imai S, Kiess W (2009) Nampt: linking NAD biology, metabolism and cancer. Trends Endocrinol Metab 20: 130-138.

38. Hasmann M, Schemainda I (2003) FK866, a highly specific noncompetitive inhibitor of nicotinamide phosphoribosyltransferase, represents a novel mechanism for induction of tumor cell apoptosis. Cancer Res 63: 7436-7442.

39. Zhang T, Berrocal JG, Frizzell KB, Gamble MJ, DuMond ME, et al. (2009) Enzymes in the $\mathrm{NAD}^{+}$salvage pathway regulate SIRT1 activity at target gene promoters. J Biol Chem 284: 20408-20417.

40. Taylor KA (1996) A sample colorimetric assay for muramic acid and lactic acid. App Biochem Biotech 56: 49-58. 